\title{
A Behavioral Change Perspective of Maroon Soil Fertility Management in Traditional Shifting Cultivation in Suriname
}

\author{
Luuk Fleskens • Fedde Jorritsma
}

Published online: 20 February 2010

(C) The Author(s) 2010. This article is published with open access at Springerlink.com

\begin{abstract}
In Suriname, the Maroons have practiced shifting cultivation for generations, but now the increasing influence of modern society is causing a trend of decreasing fallow periods with potentially adverse effects for the vulnerable tropical soils. Adoption of appropriate soil fertility management (SFM) practices is currently slow. Combining methods from cultural ecology and environmental psychology, this study identifies two groups with divergent behavioral intentions which we term semi-permanent cultivators and shifting cultivators. Semi-permanent cultivators intend to practice more permanent agriculture and experiment individually with plot-level SFM. Shifting cultivators rely on traditional knowledge that is not adequate for their reduced fallow periods, but perceive constraints that prevent them practicing more permanent agriculture. Semi-permanent cultivators act as a strong reference group setting a subjective norm, yet feel no need to exchange knowledge with shifting cultivators who are in danger of feeling marginalized. Drawing on a political ecology perspective, we conclude that cultural ecological knowledge declined due
\end{abstract}

L. Fleskens $(\varangle) \cdot$ F. Jorritsma

Land Degradation and Development Group, Soil Science Centre, Wageningen University,

P.O. Box 47, 6700 AA Wageningen, The Netherlands

e-mail: L.Fleskens@leeds.ac.uk

F. Jorritsma

e-mail: fedde.jorritsma@gmail.com

Present Address:

L. Fleskens

Sustainability Research Institute, School of Earth \& Environment, University of Leeds,

Leeds LS2 9JT, UK

Present Address:

F. Jorritsma

WECF The Netherlands,

P.O. Box 13047, 3507 LA Utrecht, The Netherlands to negative perceptions of external actors setting a strong subjective norm. Semi-permanent cultivators who wish to enter the market economy are most likely to adopt SFM. We conclude that any future SFM intervention must be based on an in-depth understanding of each group's behavior, in order to avoid exacerbating processes of marginalization.

Keywords Soil fertility management · Agricultural development · Indigenous knowledge $\cdot$ Theory of planned behavior $\cdot$ Maroons $\cdot$ Suriname

\section{Abbreviations}

LVV (Klaaskreek branch office of) the Ministry of Agriculture

NGO Non-governmental organization

NLC Nieuw Lombé Cluster, conglomerate transmigration village that forms the study area

NPK Nitrogen/Phosporus/Potassium fertilizerabbreviation according to chemical elements

OL Old Lombé, the submerged village where elder villagers lived before the transmigration

PAS Pater Ahlbrinck Stichting, a non-governmental organization

PRA Participatory Rural Appraisal

SFM Soil fertility management

TPB Theory of Planned Behavior (Ajzen 2005)

TRA Theory of Reasoned Action (Fishbein and Ajzen 1975)

\section{Introduction}

Maroon Shifting Cultivation in a Changing Context

Shifting cultivation by slash-and-burn, where forest is burnt to prepare land for agriculture, is widely practiced in the 
American tropics. This also applies to Maroons, descendants from the African slaves who fled from the colonial plantations on the coast of the Guyana Shield region (North of Brazil, Suriname, French and British Guyana) into the inland rainforests, where they established independent settlements. They are unique in that they maintained their socio-cultural identity and African traditions (St-Hilaire 2000). Suriname encompasses one of the last remaining cultural societies of Maroons in the Americas (Lenoir 1975), numbering 72,000 people (ABS 2005).

Maroons have been using the rainforest in an extensive and sustainable way and their agricultural knowledge and practices have been shaped by hundreds of years of experience. However, the Maroon communities are facing increasing commercial and governmental influence-both as a consequence of mining, logging and tourism development in their territory, and attraction of mainly young Maroons to the market economy. This influence has led to a stronger preference for economic activities over subsistence farming (Anderson 1980; Heemskerk 2003). As a consequence, a more permanent cultivation system may evolve because the labor-intensive nature of the traditional shifting cultivation system is not compatible with off-farm activities. A gradual transition from shifting cultivation to more permanent agriculture of Maroon farmers has already been observed (Vigelandzoon 2003; Topoliantz et al. 2006). However, shortening of fallows, combined with little or no use of fertilizers, may have negative consequences for agricultural productivity and agro-ecosystem integrity (Szott et al. 1999). This is especially a risk in rainforests because most nutrients are stored in dead and living organic matter and circulated in a tight cycle (Poels 1989).

In shifting cultivation systems, important losses of nutrient stocks occur: first after a plot is cut and burnt through volatilization (Budelman and Ketelaars 1974; Mackensen et al. 1996), subsequently during the cultivation period, through leaching and soil erosion, and to lesser extent through harvested products (Van der Pol 1992). However, shifting cultivation systems do not have the purpose to maintain soil fertility constant in the short term but rather sustain soil fertility by the regeneration of natural, secondary vegetation. The shifting cultivator's strategy is to have a fallow period long enough to recover soil fertility lost during cultivation (Szott et al. 1999). Soil organic matter plays a fundamental role in this process (Topoliantz et al. 2006). Soil organic matter dynamics and nutrient fluxes can be partially controlled by farmers' soil fertility management (SFM) practices.

A transition to a more permanent cultivation system will demand fundamental changes in SFM, i.e., emphasis on in situ SFM instead of plot rotation. According to Ruthenberg (1980) agricultural change occurs always under influences of socio-economic and political factors within society.
These factors can originate in internal organization or external influences. For example, Mortimore and Tiffen (1994) show how a change from a long fallowing system to a more permanent system was triggered by population growth and certain preconditions. Beshah (2003) stresses that agricultural intensification besides increasing the ratio between cultivation and fallow period may involve technological changes such as inputs, tillage and weed management. Also a systemic change, e.g., towards the development of agroforestry can be considered a technological change. Technological changes in SFM practices play an important role in farmers' capabilities to maintain soil fertility.

\section{Indigenous Knowledge and Soil Fertility Management}

While the problem of diminishing soil fertility in tropical agriculture has been acknowledged by farmers, researchers and policy makers (Stoorvogel and Smaling 1998), technological and institutional innovations targeting improving the soil have largely failed (Biot et al. 1995; Saïdou et al. 2004). One of the main reasons for this failure is a lack of understanding that many indigenous management systems are not motivated by the prediction of yields and controlling nature but apply their management practices in an adaptive way towards changing biophysical and sociocultural environments (Berkes et al. 2000; Wiersum 2000). Indigenous knowledge of soils, species and habitats ("the environment") is acquired by experiences that have been tested over generations. Beshah (2003) argues that knowledge is accumulated through utilization, mostly in the form of concrete experiences. Thus, farmers' interests and capabilities in experimentation are important elements in generating local knowledge (Corbeels et al. 2000). Many small-scale case studies of indigenous land use emphasize the role contextual and historical factors play in variations of knowledge (Clark et al. 2008). As Wiersum (2000) states, the term indigenous knowledge may better capture the meaning as locally evolved knowledge may over time be influenced and modified by external information. Maroon knowledge can thus be seen as a mixture of knowledge from cultural transmission (from one generation to the other) and adaptations of knowledge from external influences.

Intervention programs building on indigenous knowledge have been shown to contribute to rural development (Kolawole 2001; UN 2002) and sustainable resource management in tropical rainforests (Schmink et al. 1992; Laird 1999; Berkes et al. 2000). Indigenous knowledge of soils is relatively well-studied (Niemeijer 1995; Birmingham 1998; Oudwater and Martin 2003; Saito et al. 2006). In Amazonia, historical ecological research has revealed intricate knowledge of soils in prehispanic times (German 2003; Heckenberger et al. 2007), little of which can be reconstructed from contemporary indigenous knowledge 
(Winklerprins and Barrera-Bassols 2004). As far as we know, no research has been conducted to date about Maroon knowledge of soils.

The study of local knowledge of soils (or ethnopedology) can be placed in the framework of ethnoecology, coined by cultural ecologists as a hybrid approach to understand natural resource (e.g., soil) management (BarreraBassols and Zinck 2003). This framework distinguishes a belief system (Kosmos), a repertory of knowledge or cognitive systems (Corpus), and the set of practical operations of that knowledge (Praxis) - the K-C-P complex (Winklerprins and Barrera-Bassols 2004). Corpus/Praxis relations are often studied simultaneously. For example, according to Defoer and Budelman (2000) local farmers recognize soil fertility decline by the appearance or disappearance of certain plants and soil characteristics like color. Thus, SFM entails not only the practices to maintain or increase soil fertility but includes also the (cognitive) assessment of soil fertility. However, the role of local belief systems has so far been highly neglected in ethnopedological studies (Winklerprins and Barrera-Bassols 2004). Furthermore, Denevan (1983) argues that there is a danger in conceptualizing the cultural system too rigidly-leading to deterministic explanations of adaptation to change. Rather, a causal approach is needed which explains why a certain practice is applied out of an array of practical options. Indigenous knowledge is also not uniformly distributed over a society, but may be vested in some of its constituent groups (e.g., Ayantunde et al. 2008) or even households (Clark et al. 2008); this calls for a finer tempospatial scale when dealing with adaptation processes (Denevan 1983). We will in this paper seek to understand SFM from an exploration of indigenous knowledge of soils, but also explicitly take into account perceptions, motivational factors and beliefs of farmers regarding SFM. We will do so by juxtaposing a human ecology with an environmental psychology perspective.

\section{Soil Fertility Management as a Behavior}

The way farmers internalize SFM is framed by their perceptions of the world around them (Kickert et al. 1997). To understand such perceptions, in environmental psychology individual rather than societal behavior is studied (Kaiser et al. 1999). Beedell and Rehman (2000) reviewed a number of studies that have used psychological approaches to explain farmer behavior. The most widely used model was the Theory of Reasoned Action (TRA) of Fishbein and Ajzen (1975).

In the TRA, it is believed that behavior is best predicted by behavioral intention - the cognitive representation of a person's readiness to perform a given behavior (Ajzen 2005). Behavioral intention is a function of one's attitude towards a particular act (the degree to which performance of the behavior is positively or negatively valued) and one's subjective norms (i.e., the perceived social pressure to engage or not to engage in a behavior). Attitude includes not only the evaluation of certain outcomes of a particular act but also the estimation of the likelihood of these outcomes. Subjective norms refer to the perception of the expectations of relevant others (reference group), thus the strength of normative beliefs and the motivation to comply with these beliefs. Social norms are often shared by a group of individuals, supposing a collective identity (Polletta 2001; Pretty 2003; Burton 2004). In this way, norms are thus linked to self-identity. However it should be noted that individuals can identify themselves with different reference groups. This multi-identity perspective can be seen as "... structured and hierarchical, with each individual able to enact as many identities as there are social groups with which they identify" (Burton 2004: 367).

It was realized that behavior faces a limitation in its translation into action that is not considered in the TRA (Lynne and Rola 1988; Kaiser et al. 1999; Tanner 1999). This limitation was termed as perceived behavioral control in the successor model to the TRA, the Theory of Planned Behavior (TPB; Ajzen 2005). Perceived behavioral control refers to people's perceptions of their ability to perform a given behavior (Ajzen 2005). When an individual perceives lack of control, he or she will not be able to perform the action because of a lack of opportunities to perform the intended act (Beshah 2003). Therefore perceived biophysical and socio-cultural constraints determine, to some extent, which ecological behavior is easier to carry out and which is harder (Kaiser et al. 1999). This aspect is described as actual behavioral control in the TPB. Artikov et al. (2006) address another aspect of control which relates to the extent to which farmers want control over their farms. Some farmers, depending on their personality, may want more control while others may be more likely to 'go with the flow'.

The three predictors of intention (attitude, social norms and perceived behavior control) are interrelated and shaped by beliefs which are based on cultural transmission, observations, information, hearsay and last but not least experienced knowledge (Beedell and Rehman 2000). In studies applying the TPB to environmental management, different authors found different factors to correlate most strongly with behavior: e.g. perceived behavioral control (Lynne et al. 1995) or intention (Kaiser et al. 1999; Wauters et al. 2010).

\section{A Case Study on Saramaccan Maroons}

Research about Maroon farming systems is scarce (e.g., Budelman and Ketelaars 1974; Barker and Spence 1988) and does not focus on the underlying factors of SFM. We 
conducted such a focused study about the Saramaccan tribe, one of the six Maroon tribes in Suriname. Since the colonial government signed treaties with the Saramaccans and other Maroon tribes in the mid-eighteenth century, a framework of authority emerged. Each tribe has a government-approved Granman (chief) and each village has one or more Captains (headmen) who are assisted by several Basjas (adjuncts) and elderly people of the village. The Captains and Basjas are appointed by the government based on information provided by the villagers. Their function is for lifetime and they receive a monthly wage. Traditionally, the role of the officials was exercised with oracles, spirit possession, and other forms of divination (Price 1975) but nowadays they address and solve problems by organizing village meetings and communication through the Basjas, rendering the village effectively the basic unit of the formal socio-political structure. The Maroon tribes are divided into $L o ́$ which are matrilineal and possess their own territory, although a single Ló may be found in several villages, while there are usually several Ló within a particular village (Anderson 1980). The Ló in turn, is divided into Bee-extended family units including second grade family members.

In the last 50 years drastic changes have taken place among 28 Saramaccan communities which were forced to move to so-called transmigration villages due to the construction of a dam by the government. In this paper, we seek to understand agricultural change that was catalyzed by this experience whereby we focus on the underlying processes of behavioral change in SFM. These processes are crucial since a transition to more permanent agriculture that is not accompanied by the simultaneous generation and application of more specific knowledge on soil fertility could be disastrous for the vulnerable tropical soils and the people's livelihoods. We start from the hypotheses that: a) the generation of indigenous knowledge is intricately linked to farmers' practical experiences and experimentation; b) behavioral change processes differ across a community's constituent groups; and c) insight in each group's behavior allows intervention programs to design strategies which facilitate changes towards sustainable SFM. As such, this study contributes to the objective of the Guyagrofor (Guyana-agroforestry) research project: understanding Maroon and Indigenous traditional practices and finding ways to incorporate their knowledge of the rainforest ecosystem into sustainable agroforestry practices (Vigelandzoon 2003).

\section{Approach and Methodology}

We will approach SFM from a multidisciplinary view which includes soil fertility assessment and soil fertility practices. It is assumed that farmers' behavior can best be understood from an interwoven historical, perceptional, and behavioral context (Fig. 1). The perceptional context is an interplay of biophysical (e.g. local soil classification), sociocultural (e.g. knowledge exchange), institutional (e.g. sources of knowledge) and socio-economic (e.g. off-farm income) factors. The behavioral context is shaped by farmers' attitude (e.g. adoption of SFM practices), subjective norms (e.g., farmers' traditional belief system) and perceived behavioral control (e.g., time and financial constraints) as has been suggested in the TPB.

Several authors have recommended an anthropological approach rather than a structured survey approach for collecting indigenous (soil) knowledge (Maundu 1995; Niemeijer 1995; Birmingham 1998). Oudwater and Martin (2003) emphasize the complexity and contradictions of indigenous knowledge. Therefore, it is crucial to question from where the differences and inconsistencies come by designing an approach from a broad description to a more detailed analysis and by continuously cross-checking the collected information. Warren et al. (1995) suggest that an understanding of farmers can be acquired by studying historical perspectives, agricultural landscapes and agricultural systems, as well as by talking with individual rural residents. In our study we adopted several iterative and interactive methods to achieve this. In doing so we followed Burton (2004: 368) who argues that "it is generally advantageous to combine qualitative and quantitative work (...) to ensure that a balance is struck such that the quantitative data is not ignored." In the context of applying the TPB, compatibility of units of analysis is an important consideration (Burton 2004; Wauters et al. 2010), and "trying to correlate general attitudes or normative measures with specific agricultural behaviors (...) is unlikely to prove a particularly enlightening exercise" (Burton 2004: 368). Perceived behavioral control in this study is assessed from balanced quantitative and qualitative data, while attitudes and social norms are mainly derived from qualitative information, for example, quotes from open questions, unofficial field notes and impressions.

\section{Study Area}

The study was conducted in the Saramaccan Maroon village of Nieuw Lombé Cluster (NLC), situated in the Brokopondo District of Suriname on the east bank of the Suriname River, about $150 \mathrm{~km}$ south of the capital Paramaribo. During the transmigration in 1964 villagers from the now submerged village of Old Lombé (OL) had to move either south (upstream) or north (downstream) of the Brokopondo Reservoir. Those who moved north established themselves in NLC where houses were built in advance by the government. The village is a so-called conglomerate transmigration village consisting of the subvillages Munjekriki, Nieuw Lombé and Kapasikele, respec- 


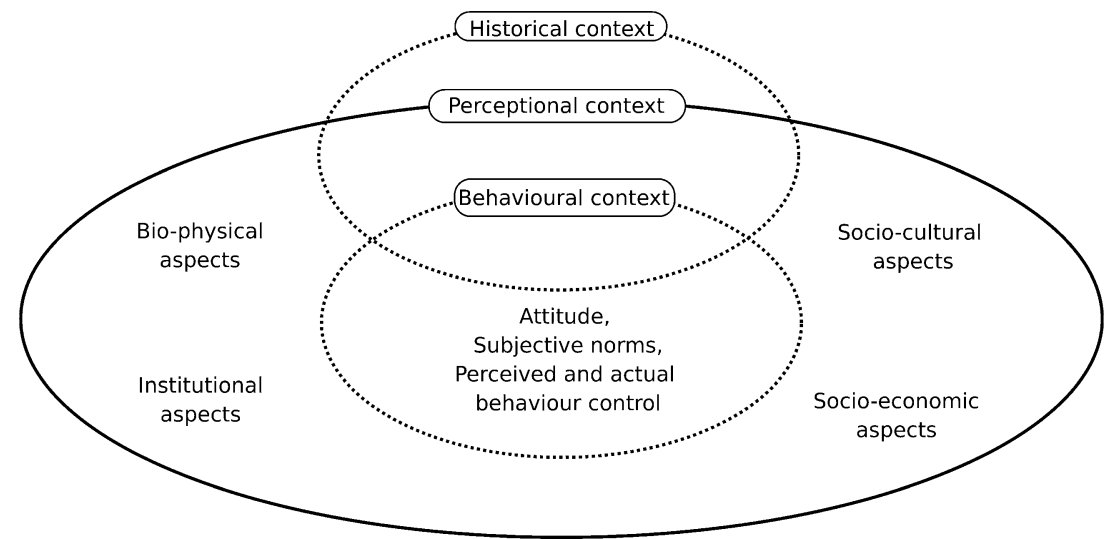

Fig. 1 Analytical framework of the study

tively having 100-150, 200-250, and about 50 inhabitants above 18 years (Knoblauch 2006). An estimated 150-200 farmers have a plot in the surrounding area of NLC.

The climate of the Brokopondo district can be classified as equatorial rainforest, fully humid (Af) in the KöppenGeiger system (Kottek et al. 2006). Usually four seasons are distinguished (Mulders and Bruin 1973): 1) a short rainy season, from mid-December to January; 2) a short dry season, from February to April; 3) a long rainy season, from May to mid-August; and 4) a long dry season (midAugust to mid-December). Only in the long dry season is the evapotranspiration higher than the precipitation. The mean annual rainfall in Klaaskreek-located opposite NLC on the west bank of the Suriname River-over the period 1972-1985 was 2,590 mm (Meteorological Service Suriname, unpublished data).

Geologically the area belongs to the Guyana Shield, a basal complex originating from the Precambrian age $(2,600$ million years ago). Residual soils often have a red, yellow or brown color due to formation of iron and aluminum oxides (ferralization) and are well drained. They are classified as Ferralsols (FAO system; Driessen and Dudal 1991) or Oxisols (USDA Soil Taxonomy) and form a rolling to hilly landscape, crisscrossed with creeks. The Suriname River has created a landscape dating from the Pleistocene age, moving away from the river respectively consisting of embankments, valleys and terraces. Embankments and valleys both have fine sandy loam or clay texture but differ in drainage condition: moderate and poor, respectively (Van Vuure 1971). The valleys are flat with creeks that drain in the Suriname River. The landscape of river terraces is slightly rolling. The soils are well to moderately well drained and have a coarse sandy loam texture with humusrich top soil (Van Vuure 1971). Soils in all river landscapes are classified in the FAO system as Fluvisols (or as Fluvents in USDA) (Driessen and Dudal 1991).

The original vegetation of the Suriname interior consists of tropical rainforest. In the surroundings of Maroon villages a mosaic of forest of different growth stages has arisen (Hendrison 2002). Especially the river valleys and terraces consist of this mosaic of secondary forest, since the Maroons live mostly near the rivers.

\section{Field Methodologies}

Fieldwork was conducted from September 2005 to February 2006. Data was collected by Participatory Rural Appraisal (PRA) tools, a farmer survey $(n=24)$, field visits with in-depth interviews and observations $(n=21)$, and informal and key informant interviews $(n=11)$. Before field work commenced, a village meeting was convened where the researchers of the Guyagrofor project introduced themselves and villagers were informed about the purpose of the project. In this meeting, the villagers also worked on the first two PRA tools. Interviews were conducted in Dutch when interviewees mastered this language, or with two-directional interpretation by project staff members in Sranan Tongo. Soil drillings, transect-walks and photographing were performed during the field visits.

\section{The Farmer Survey}

The purpose of the farmer survey was to collect quantitative data. Parameters were derived from literature about studying farmers' indigenous knowledge (Maundu 1995; de Graaff et al. 2001; Butterworth et al. 2003; Oudwater and Martin 2003) and included household composition, income generation activities, plot characteristics, detailed description of agricultural systems, (planned) cultivation/ fallow time, labor input, soil fertility indicators and sources of agricultural knowledge. A total of 24 farmers were interviewed, who were selected by: 1) Location of residence in order to cover a wide geographical area; 2) Gender, assuming differences in perceptions and knowledge between men $(n=13)$ and women $(n=11)$, e.g., due to traditional division of labor; and 3) Age, assuming difference in knowledge between 
generations, e.g., old is often associated with 'wise' and 'knowledgeable'. However, the first criterion was not completely achieved because only one farmer from Kapasikele was interviewed versus 15 from Nieuw Lombé and 8 from Munjekriki. Within the third criterion a division is made between elderly farmers ( $\geq 50$ years) $(n=10)$ who have lived in $\mathrm{OL}$ in the past and younger farmers $(<50$ years $)(n=14)$.

\section{PRA Tools}

Before, during and after the farmer survey the following PRA tools were used with groups of different composition (gender, age, and village):

- Agricultural (labor) calendar: nine farmers of mixed gender were asked to divide the shifting cultivation system into several phases and indicate timing and gender division of activities;

- Soil classification: the same nine farmers went on to name the soil types in the area and mention their identification criteria;

- Timeline mapping: with the help of two elders, in order to have a brief historical overview and to identify the main events that took place in village, forest and agriculture;

- Community soil mapping: three knowledgeable persons (two from Nieuw Lombé and one from Kapasikele) were asked to indicate 1) the soil distribution in the area; 2) perceptions on spatial variation of soil fertility; and 3) land pressure on a large map;

- Ranking plot selection criteria: in order to understand how plots are selected by farmers. Twenty cashew nuts had to be assigned among 10 criteria for selecting a plot, departing from the notion that they were equally important. One session was done with seven men and two sessions were held with women, respectively with two and three participants. During the sessions considerations and discussions of the group members were written down; and

- Advantages and disadvantages of SFM practices: a group of eight women and one man were asked to mention advantages and disadvantages of each practice derived from the farmer survey.

\section{Field Visits with In-depth Interviews and Observations}

After the farmer survey, field visits were conducted to link information obtained previously with physical observations in order to confirm or obtain more detailed information about certain subjects. Questions were prepared in advance but often based on observations in the field - e.g., farmers were asked to indicate 'good' and 'bad' sites and places where they wanted to plant certain crops. This information was checked by transect-walks across the plot, often from low to high places. The location in the field, state of crops, litter layer and groundwater level were documented. In total 21 fields were visited.

\section{Key Informants}

Eight key informants, mainly elders, were interviewed to obtain an understanding of SFM in OL, traditional knowledge and perceptions of SFM-related issues in the village. The key informants were identified by village leaders, informal talks and themselves (snowball-sampling). Interviews were of a semi-structured nature, with subjects focused on: 1) how Maroons assess(ed) soil fertility and which identification criteria they use(d);2) past and present ecological knowledge of Maroons about soil fertility; 3) how Maroons maintain(ed) their soils fertile and how they use(d) their knowledge of soil fertility; 4) how knowledge on soil fertility of Maroons is/was distributed among men, women, the elderly and youth; 5) the communal organization and belief systems in relation to SFM; and 6) the future perspectives and needs of Maroons regarding to SFM. Besides villagers, also three other informants were also interviewed. They were representatives of organizations who were active or had been active in NLC, including the Ministry of Agriculture branch office (LVV-Klaaskreek) and the NGO Pater Ahlbrinck Stichting (PAS).

Information Processing and Analysis

Data from the farmer survey and field visits were stored in a database and PRA tools and interviews were worked out in separate text documents. Percentages and means ( \pm standard errors of means) were calculated for quantitative data. So-called R-factors were calculated as the ratio between cultivation period and sum of cultivation and fallow period, expressed in per cent (Ruthenberg 1980). Notes of historical data from literature were supplemented and checked with information from elderly villagers. Sources of external knowledge were determined and checked with the institutions that supposedly provided the information.

Throughout the paper a distinction is made between traditional knowledge (perceptions, beliefs and practices passed down by previous generations) and external knowledge (adapted from outside the village by the current generation). In order to analyze differences in SFM, a distinction is made between farmers who intend to stay longer than two years on a plot and farmers who incline to move after one or two years. Statistical analyses were performed to test significance of these differences: Fisher's Exact Test for nominal data (this test is appropriate for $2 \times 2$ tables when expected cell frequencies are low), and student's $t$-test for interval data (after verifying that both 
data series are normally distributed, which is a requirement when sample size is small). These two types of farmers are compared with the traditional shifting cultivation system in OL. Finally, sayings of villagers are occasionally literally translated and Saramaccan words are used to give the context situation. These statements are put in quotation marks and Saramaccan words are italicized.

\section{Farmers' Perceptions of Soil Fertility}

Indicators of Soil Quality

Thirty-seven farmers mentioned indicators for 'good' or 'bad' soils during the farmer survey, in-depth interviews and informal interviews (Table 1). This wide range of indicators was used by farmers to select their plot and to determine where to plant the different crops. The principal indicator for soil quality is the performance of initial crops like watermelon (Citrullus vulgaris), okra (Hibiscus esculentus), maize (Zea mays), cucumber (Cucumis sativus) bitter gourd (Momordica charantia), sugarcane (Saccharum officinale) and eggplant (Solanum melongena). This was especially mentioned by women. Texture and water holding capacity of the soil were mostly mentioned by men. However, women associated factors like a low temperature and dark colored soils with a high water holding capacity. These soil characteristics were also indicated as important criteria during group discussions about the factors determining plot selection. Drainage was often linked to texture and compaction. Dark colored soils, rich in humus, were generally perceived as productive for a wide range of crops. Some women mentioned the abundance of roots in the soil as a disadvantage of using old secondary or primary forest because it lowers production.

\section{Soil Classification}

During the soil classification people indicated four soil types: blakka doti (black soil, rich in humus), santi doti (sandy soil), potto potto (clay) and redi doti (red soil) (Table 2). The most important method to recognize a soil type is by touch. When the particles feel coarse, soils are sandy, while soils that feel finer consist of clay particles. Sandy soils are perceived as hot when treaded with bare feet, while black soils feel colder. The water holding capacity of black soils was mentioned by a few people: "it feels wet throughout the year". Soil types were often associated with location and altitude; for example clay soils are found on low sites, especially along the river, while black soils are found in the primary forest. Sandy soils are found in higher places.

The rough classification of soils and the large differences in characteristics make it quite easy for the people to distinguish these soils. However, most plots contained a mix of different soil types, for example: santi moxsi blakka doti. In some cases farmers mentioned different proportions of soil types on their field. For example: more black soil on the slope and more sandy soils on the hill, while both sites were described as santi moxsi blakka doti. People never referred to the subsoil and could mostly only describe the first 30 to $40 \mathrm{~cm}$. However, a few respondents perceived the layer beneath the topsoil as redi doti which were characterized as compact and unproductive soils.

The soil classification is often used to classify soils on suitability for particular crops-the soil types are not directly linked to productivity. Each crop needs different soil conditions to get an optimal production. One man said: "It is like a man who chooses a woman; if it hits off they will produce a lot of children." According to a woman interviewed: "It is like a mother who does not have the

Table 1 Indicators of soil quality in the context of plot selection and planting strategies

\begin{tabular}{|c|c|c|}
\hline Indicator & Reasons given by the farmers & $\%^{\mathrm{a}}$ \\
\hline $\begin{array}{l}\text { Growth and yield of } \\
\text { initial crops }\end{array}$ & The growth of the initial crops like watermelon, okra, cucumber and maize reveals the best spots in the field. & $57 \%$ \\
\hline Dark colored soils & Black soils are perceived as productive soils because of their wide crop range and water-holding capacity. & $30 \%$ \\
\hline Temperature of the soil & A cool soil indicates a high water-holding capacity. & $27 \%$ \\
\hline Water-holding capacity & $\begin{array}{l}\text { Soils which contain moisture throughout the year are perceived as productive soils. Black soils are } \\
\text { often associated with a high water-holding capacity. }\end{array}$ & $19 \%$ \\
\hline Drainage & Inundation in the field is perceived to give a bad crop production (often associated with clayey soils). & $19 \%$ \\
\hline Roots in the soil & A lot of roots in limit the production. This situation is mostly confined to soils in primary forest. & $16 \%$ \\
\hline Texture & Some crops need a specific texture for a good production. Texture was often also related to drainage. & $16 \%$ \\
\hline Crop range & The more crops have a good harvest on a particular soil, the better the soil is perceived. & $14 \%$ \\
\hline $\begin{array}{l}\text { Vegetation before } \\
\text { burning }\end{array}$ & $\begin{array}{l}\text { Big fat leaves with fruit in the trees indicate a healthy soil. In addition the more vegetation the more ash } \\
\text { which is seen as fertilizer. }\end{array}$ & $14 \%$ \\
\hline
\end{tabular}

${ }^{a}$ Percentages are derived from the farmer survey, in-depth interviews and informal interviews (total of 37 farmers). Most farmers mentioned different indicators. 
Table 2 Indicators, locations and crops of different soil types

\begin{tabular}{lllll}
\hline Soil type & Potto potto (clay) & Blakka doti (black soil/humus) & Santi doti (sandy soil) & Redi doti (Red soil) \\
\hline Indicators & $\begin{array}{l}\text { Fine feeling; muddy; cool; } \\
\text { brown/yellow; water accumulation; } \\
\text { crusting; compact }\end{array}$ & $\begin{array}{l}\text { Black; cool; holds moist; contains } \\
\text { humus and charcoal }\end{array}$ & $\begin{array}{c}\text { Hot; coarse feeling; dry; } \\
\text { white; loose }\end{array}$ & Red \\
Where found & $\begin{array}{l}\text { Along the river and creeks; } \\
\text { low sites }\end{array}$ & In the forest; in the village & Inlands; high sites & $\begin{array}{c}\text { Hilly sites; under } \\
\text { the topsoil }\end{array}$ \\
Main crops $^{\text {a }}$ & $\begin{array}{l}\text { Rice, (cooking) banana, } \\
\text { pomtayer and sweet potato }\end{array}$ & Wide crop range & $\begin{array}{c}\text { Cassava, napi, groundnut } \\
\text { and ginger }\end{array}$ & None mentioned \\
\hline
\end{tabular}

Village meeting and field visits

${ }^{\mathrm{a}}$ The first crop is mentioned most by people

capacity to raise a disabled child and is looking for a special institute which can help her child."

Cooking banana / banana (Musa sapientum / Musa paradisica), pomtayer (Xanthosoma sagittifolium), sweet potato (Ipomoea batatas) and rice (Oryza sativa) are perceived to perform well on potto potto. However some clay soils along the river or creeks posed problems: in dry periods, the soil got crusted while in wet periods water accumulated on the field. Sandy soils were indicated as productive for cassava (Manihot esculenta), napi (Dioscorea trifida), groundnut (Arachis hypogaea) and ginger (Zingiber officinale). The humus-rich blakka doti are indicated as soils suitable for a wide range of crops. These soils were generally perceived as 'good' but none of the farmers mentioned the nutrient status as an underlying factor. People had little experience with redi doti soils because they are not found in the surrounding areas.

\section{Soil Distribution and Quality}

During a soil mapping exercise people from NLC had drawn a soil map with their perceptions about the soils (Fig. 2). The shifting cultivation area is concentrated around the villages and extends in-land up to about four kilometers. The physical access to land is by little paths in the forest. Three main creeks were identified: Stokko kriki to the south of Munjekriki; Dokko kriki and Kris kriki situated between Nieuw Lombé and Kapasikele. Forest that has not been cut for a long time (over 25 years) is called Bigi busi and perceived to have very good (blakka doti) soils. The shifting cultivation area is called Kapoeweri (literal: cut again) and consisted of potto potto, potto potto moxsi santi doti, blakka moxsi santi doti and santi doti. Along the river and creeks people indicated potto potto which fades into potto potto moxsi santi doti with increasing distance from the river or creek. These soils are generally perceived as good to very good. Some people referred to a very productive area called Jarikaba nearby the river and dissected by Dokko kriki. Blakka moxsi santi doti are found in the interior and also seen as good soils. An exception is the blakka doti with sand between Dokko kriki and Kris $k r i k i$. This is an area where citrus trees have been cultivated for about 20 years. Around Nieuw Lombé and Munjekriki sandy soils are found, which were perceived as bad.

\section{Farmers' Soil Fertility Management Practices}

Phases of the Shifting Cultivation System

This section explains the shifting cultivation system as currently practiced in NLC. It also highlights changes relative to the system practiced in OL before the transmigration. In the village meeting, eight phases were distinguished in the shifting cultivation system (Fig. 3). The individual phases will be discussed below.

\section{Plot Selection}

The initial phase of shifting cultivation is the selection of a plot (luku basu). The occurrence of certain bad spirits (kunu's) was of great importance for plot selection in OL (Green 1978; Hoeree 1983; key informants). The boa constrictor (papa sneki), woodlouse (akantamasi) and big trees-especially the silk-cotton tree Ceiba pentandra (kankan) -were perceived as potentially inhabited by kunu's. When these kunu's are disturbed they can bring bad luck. These mystical criteria still exist in NLC but were not perceived as important during the ranking exercise of plot selection criteria. Participants even exclaimed that "people have to believe in God" and that "spirits are idolatry".

Whereas traditionally the man selected and prepared a parcel after consulting his wife and her mother (family head), today some women select their own plots. Men and women manifest a different strategy in plot selection. Men prefer a short distance to the homestead and to a creek or river because of good drainage and water holding capacity of the field. However, just a few farmers (23\% of men) are actually cultivating on these locations, probably because the land is already claimed by other Bee's. Both men and 


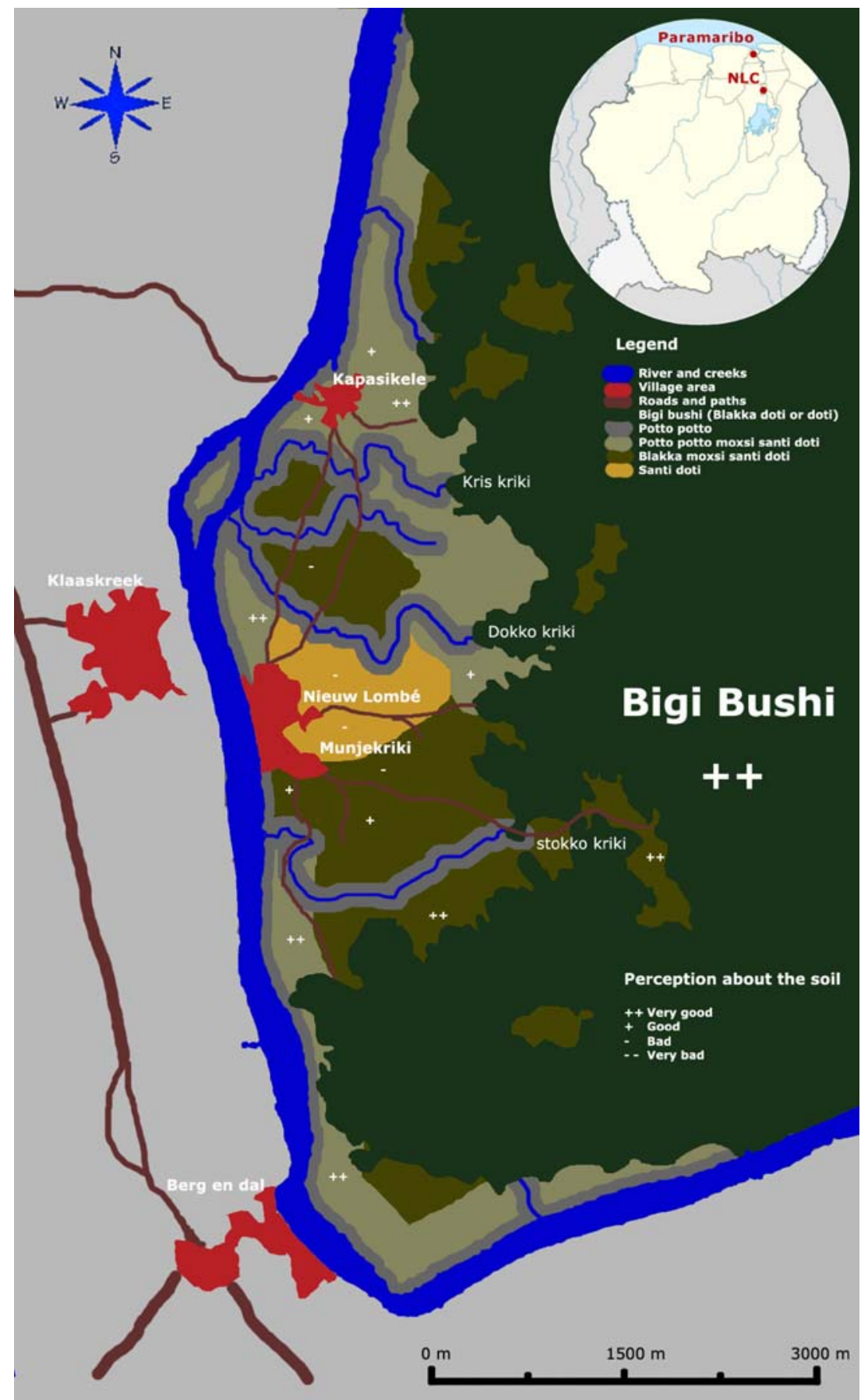

Fig. 2 Map of NLC with farmer's perceptions about the soil (scale derived from Google-Earth, 2006)

women prefer to have a variety of soil types on their plot. This was confirmed in the field $(45 \%$ of the farmers surveyed had two or more soil types).

\section{Cutting the Lower Forest Layer}

After the plot is selected, first the bushes, lianas and small trees are cut down (koti basu). This is done separately because bigger trees can fall down on the bushes in such a way as to impede cleaning, rendering the subsequent burning process less effective. The cutting process takes about five man days depending on the size of the parcel. The bushes have to dry for about two weeks.

\section{Cutting the Trees}

After cutting the lower forest layer, the trees are felled ( $f a a$ goon). In most cases all trees and palms are cut, although 
Fig. 3 Phases of the shifting cultivation system NLC with timing and gender. Source: PRA tool at village meeting

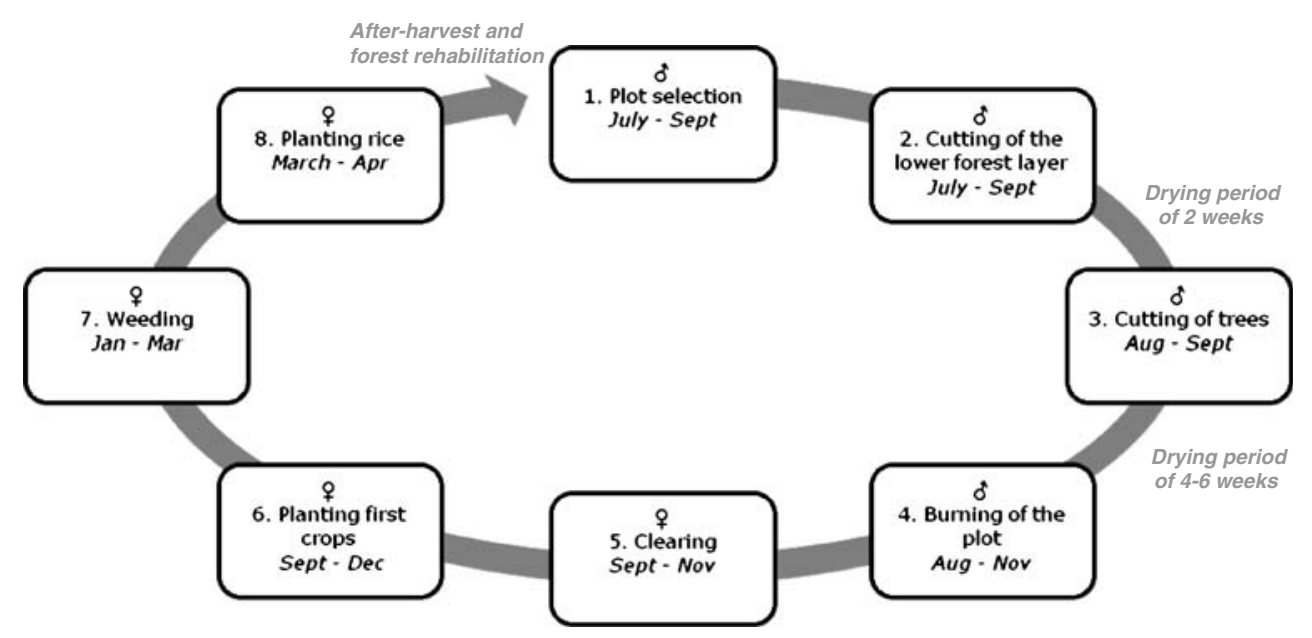

the longfruited rose-apple (Eugenia manaccensis) is sometimes left for its edible fruits. The trees are cut in such a way that the burning process will be efficient, usually by axe, but increasingly by (hired) chainsaw. A few people (13\% of the farmer survey) own chainsaws. Trees of economic value are directly sawn in useful pieces and removed. The duration is also about five man days to clear the whole parcel. Cutting the forest was in OL perceived as tough and dangerous work because of the potential contact with kunu's and therefore exclusively done by men (Eduards 1996).

\section{Burning the Plot}

After a second drying period of four to six weeks, the farmer (mostly men) starts burning the plot (tjuma goon). Usually people burn their parcel when it has not rained for several days. It is important to choose the right moment because when the parcel is not burned well, it takes a lot of effort to clean it. In OL, after burning the terrain was inspected by the men for dead snakes (boa constrictor) which would indicate the creation of kunu's.

\section{Clearing the Plot}

After burning, women start clearing the plot (wooko goon). Vegetation which had not burned well is put on piles and burned again. The piles are often situated next to tree trunks so that these will burn as well. Unburned and immovable trunks are left on the plot.

\section{Planting the First Crops}

Watermelon is planted immediately after burning and clearing the plot while other initial crops are sown after the first rains so that the soil has cooled down. Most farmers (71\%) sow the first crops by trial and error to identify places where they grow best. This results in a highly irregular spatial crop distribution, with concentrations on places where ash had been accumulated during the burning process. Maize is sometimes planted in rows along tree trunks, a practice farmers were told to have learnt from their parents. This practice was observed to make use of 1) the shadow of the trunk which protects the germ against the heat of the sun; 2) ash accumulations along the trunk; 3) protection against itching parts of the maize plants when walking through the field. Tuberous crops and bananas are often also planted during the first cropping period with the purpose of harvesting from July till September the next year. In OL, the same crops were grown, but green vegetables were often collected from the forest (Hoeree 1983; key informants).

The villagers in NLC do not have livestock other than some poultry. Manure from the village is therefore not used in NLC. A few farmers (17\%) used NPK fertilizer (named for containing the elements Nitrogen, Phosphorus and Potassium) to enhance crop production, $13 \%$ used chicken dung bought in the city. One person said to use it only for bananas; the others apply it to crops which do not develop well. In a group discussion, elderly women argued to have no knowledge on how to use NPK or chicken dung. In the farmer survey these products were indeed found not to be used by this group.

\section{Weeding}

Farmers use four methods to remove weeds: by hand, by machete, by hoe and with gramoxone-a chemical herbicide. Weeding by hand is mostly done on sandy soils because they are loose and weed density during the cropping season is low. According to the farmers, gramoxone is fast and effective to kill weeds. However, it is expensive and a sprayer is needed. All men above 50 in the farmer survey used gramoxone. Many of them $(80 \%)$ have an off-farm income and thus capital to buy gramoxone. Presumably this group also uses the herbicide because 
weeding is perceived as very intensive work causing potential back problems. Women have little experience with chemicals.

Five methods are identified to use the weeds or get rid of them, in decreasing order of importance for SFM: 1) incorporated in the soil (applied by $58 \%$ of farmers in the farmer survey); 2) mulched $(50 \%) ; 3$ ) put on piles; 4) burned (25\%); or 5) composted (13\%). Different methods are used under different circumstances. Mulching (leaving chopped weeds distributed over the field) for example, was observed under tall crops or trees like cassava, banana or citrus. Incorporation of weeds in the soil with a hoe is confined to field bed preparation for rice. Weeding is done when the weeds are higher than the crops or "on the feeling". In OL, weeds were burnt on piles. Spontaneous weeds around the initial crops were normally not eliminated until seed bed preparation for rice.

During a group discussion with eight women, farmers were asked to mention (dis)advantages of these methods. Incorporation in the soil was solely practiced for field bed preparation of rice to make the soil loose, which is considered to have a positive effect on crop growth. The group had a lack of experience of this method in other crops. Mulching was seen as cheap and fast, but weed regrowth occurs during rainy periods. Some believed that a 'clean' plot gives better production. Therefore the weeds are put on piles and sometimes burned. Burning is cheap and fast, ash can be used as fertilizer, and thorns are burned away. No disadvantages were mentioned. Members of women's organizations had learned to make compost by PAS (for homestead vegetable gardening). Although the group acknowledged the value of compost as a fertilizer, no one made compost on their plot. This could be due to its making being regarded as a tedious process, and that compost attracts snakes. Not performing any weed management was not an option because of competition for water.

\section{Planting of Rice and Groundnut}

People often indicated the lowest site(s) in their plot as the most suitable place to cultivate rice (diki goon). Paddy is broadcast after an initial seedbed preparation. Five months later the rice is ready to harvest. Traditionally, this was the moment to start selecting another plot. However, sometimes rice was planted a second time (Budelman and Ketelaars 1974; key informants).

In NLC, $42 \%$ of farmers cultivate groundnut. The majority do this after the rice harvest, although some plant groundnut already in the first cropping season. Four members of women's organizations cultivated groundnut on their plot. They had learnt this from PAS and knew that groundnut improves the soil.

\section{After-Harvest and Fallowing}

After the last crops have been harvested, the plot is left. However it is often still used for harvesting bananas, cassava, ginger and other perennials, and to collect planting materials for the next plot. This after-harvest period varies between one and five years depending on productivity, regrowth rate of secondary forest and distance to the new plot.

\section{Development Towards a More Permanent Agriculture}

Some farmers have started to practice more permanent agriculture. Experimentation by farmers showed little uniformity. One farmer had been using his plot for 20 years but had fallowed his plot several times for some years. Another farmer, who was cultivating a clayey soil, said he used a system of two year cultivation and two year fallowing and was doing that for five years now. A farmer who had his plot on more sandy soils had been cultivating for three years on the same plot and fallowed his land each year for five months. The longest cultivation period on one plot mentioned by a farmer was five years. His plot had a sandy loam texture. This farmer did not use fertilizer; instead, he said he improved the soil with groundnut. During the five years, he had not observed a decrease in production.

Besides the traditional crops, vegetables like tomatoes (Lycopersicon esculentum), celery (Apium graveolens) and hot peppers (Capsicum frutescens) are grown, which are sometimes germinated in cups. According to farmers' experience over the years, the tuberous crops cassava and napi are doing well but rice and banana are giving less production. A few farmers mentioned that watermelon and maize need additional fertilizers. Farmers experiment with additional fertilizers in the form of chicken dung, compost or NPK. The use of chicken dung is perceived as more effective than NPK. One farmer reasoned: "NPK washes easily away by the rain". However, chicken dung is more expensive than NPK. Hence, a few farmers wanted to start up chicken farming.

Composting of the weeds on the plots is done by three farmers. One farmer dug a hole into the ground and put the crop residues and weeds in it after which he covered it with a sand layer. Another farmer used to put the compost on a pile and covers it with plastic sheet. She also puts chicken dung and wood shred as additional nutrients to the compost. The decomposing period was about two to three months.

One farmer had planted grass species to reduce erosion from his plot. Another uses the leaves of Leguminosa as green manure when short of cash to buy chicken dung. A third maintained her soil fertility by alternating between cassava and groundnut. She has done that now for three 
years. Yet another farmer has planted the Leguminosa Kudzu (Pueraria lobata) around his citrus trees while he kept the area under the canopy bare. The trees were 8 years old and regularly fertilized with NPK.

\section{Recent Changes in Soil Fertility Management}

The traditional cultivator in OL practiced long fallows, determined the spots to plant initial crops by trial and error, burnt weeds and did not use additional fertilizers. These practices are still encountered in NLC, but fallow periods have shortened, weeds are mostly used as mulch and some farmers plant groundnut which fixes nitrogen into the soil. Moreover some farmers are experimenting to cultivate longer on a plot, and use fertilizers like NPK, chicken dung or compost to gain (local) soil fertility knowledge (Table 3). In this view, a differentiation is made between farmers who intent to practice more permanent agriculture and farmers who do not. Those who want to stay at least three years on the same plot are considered as semi-permanent cultivators ( $38 \%$ of the farmer survey), the remaining group as shifting cultivators (Table 4).

The overwhelming majority of semi-permanent cultivators is male. Women are generally shifting cultivators. Gender composition of shifting cultivators and semi-permanent cultivators is significantly different $(P<0.05)$. Semi-permanent cultivators invariably have off-farm income they can rely on, while for $60 \%$ of shifting cultivators agriculture is the only source of income. This difference is very significant $(P<0.01)$. Many semi-permanent cultivators are therefore part-time farmers. Labor input in the agricultural plot is consequently considerably lower for semi-permanent cultivators. Moreover, semi-permanent cultivators economize on travel time to their plots: on average they use less than half the time needed by shifting cultivators. The length of the cultivation period is significantly longer for semi-permanent cultivators; however, as some semi-permanent cultivators had just started to practice more permanent agriculture their average cultivation period is still underestimated. The fallow period practiced before the current plot was cultivated is for the same reason not representative of the farming systems of semi-permanent cultivators, and was therefore not significantly different from that of shifting cultivators. Nonetheless, the difference in the $\mathrm{R}$-factor calculated from both periods is already very significant $(P<0.01)$. The one striking difference regarding weed management is the abstinence from burning on the part of semi-permanent cultivators, while $40 \%$ of shifting cultivators still burn weeds. Shifting cultivators unanimously applied mixed cropping as a trial and error method for finding the spots where crops perform best, while semi-permanent cultivators predominantly planted crops in rows $(P<0.01)$. In both categories, gramoxone and NPK were used by some farmers. However, chicken dung was only used by some semi-permanent cultivators. Combining information about the application of compost, NPK and chicken dung, two thirds of semi-permanent cultivators practice at least one of those SFM practices whereas only $20 \%$ of shifting cultivators did the same. Other differences were regarding crops grown. Generally, banana, tuberous crops and rice are less appreciated by semi-permanent cultivators, although the difference was not always significant. Ginger, okra and watermelon show the same trend. Eggplant, pepper, groundnut and tomato on the other hand, are grown more frequently or newly introduced on the plots of semi-permanent cultivators. Cassava and napi are typically grown for household consumption, while eggplant and pepper are chiefly cash crops. Overall, semi-permanent cultivators tend to grow fewer different crops.

\section{Soil Fertility Management in a Behavioral Perspective}

Farmers' Knowledge of Soil Fertility in an Historical Context

Farmers' ecological knowledge of soil fertility is traditionally focused on plot selection. An important plot selection

Table 3 Recent changes of soil fertility management

\begin{tabular}{llll}
\hline & The traditional cultivator in OL & The shifting cultivator in NLC & The semi-permanent cultivator in NLC $^{\text {a }}$ \\
\hline Cultivation period & $1-2$ yrs & $1-2$ yrs & Up to 5 yrs \\
Fallow period & $10-20$ yrs & $4-10$ yrs & None \\
Plot selection criteria & Spiritual, biophysical & Biophysical & Short distance, biophysical \\
Planting strategies & Scattered, according to & Scattered, according to & In rows, mixed cropping after experience \\
& crop performance & crop performance & Mulching, composting \\
Weed management & Burning & Burning, mulching & Use of NPK or chicken dung \\
Additional fertilizers & None & Use of NPK & Groundnut, Kudzu \\
Cultivation of Leguminosa sp. & Groundnut (very limited) & Groundnut & Agroforestry, planting grass \\
Erosion control & None & None &
\end{tabular}

${ }^{a}$ The differentiation between shifting cultivator and semi-permanent cultivator is made by the intention of farmers to stay longer than 2 years on the same plot 
Table 4 Characterization $( \pm \mathrm{SE})$ of the shifting cultivator and semi-permanent cultivator in NLC

\begin{tabular}{|c|c|c|c|c|}
\hline \multirow[t]{2}{*}{ Variable (unit) } & \multirow[t]{2}{*}{ Shifting Cultivator $(n=15)$} & \multirow[t]{2}{*}{ Semi-permanent Cultivator $(n=9)$} & \multicolumn{2}{|l|}{ Statistics } \\
\hline & & & Test $^{\mathrm{a}}$ & Result $^{\mathrm{b}}$ \\
\hline \multicolumn{5}{|l|}{ About the farmer } \\
\hline Gender ( $\%$ female $)$ & 67 & 11 & FET & $p=0.011^{* *}$ \\
\hline Age (yr) & $50.2 \pm 2.8$ & $41.6 \pm 3.9$ & $t$-test & $t=1.814^{*}$ \\
\hline Only agricultural income (\%) & 60 & 0 & FET & $p=0.004 * * *$ \\
\hline Fulltime farmer $(\%)$ & 67 & 11 & FET & $p=0.011^{* *}$ \\
\hline \multicolumn{5}{|l|}{ About the plot } \\
\hline Labor input (h week $^{-1}$ ) & $32.9 \pm 3.4(n=14)$ & $17.0 \pm 2.0(n=8)$ & $t$-test & $t=3.341 * * *$ \\
\hline Distance to plot (min) & $22.0 \pm 2.8$ & $10.0 \pm 3.0$ & $t$-test & $t=2.770 * *$ \\
\hline Cultivation period (yr) & $1.4 \pm 0.1$ & $2.4 \pm 0.5(n=8)$ & $t$-test (df 8.15) & $t=2.037 * *$ \\
\hline Fallow period $(\mathrm{yr})$ & $9.2 \pm 1.2(n=13)$ & $6.3 \pm 1.5(n=8)$ & $t$-test & $t=1.483 \mathrm{~ns}$ \\
\hline $\mathrm{R}$-factor $(-)$ & $15.3 \pm 2.0(n=13)$ & $30.4 \pm 4.9(n=8)$ & $t$-test (df 9.31) & $t=2.856^{* * *}$ \\
\hline \multicolumn{5}{|l|}{ Weed management } \\
\hline Burning (\%) & 40 & 0 & FET & $p=0.037 * *$ \\
\hline Put on piles (\%) & 53 & 56 & FET & $p=0.700$ \\
\hline Mulching (\%) & 40 & 67 & FET & $p=0.200$ \\
\hline Composting (\%) & 7 & 22 & FET & $p=0.308$ \\
\hline \multicolumn{5}{|l|}{ Other agricultural practices } \\
\hline Mixed cropping (T\&E) (\%) & 100 & 22 & FET & $p=0.000^{* * *}$ \\
\hline Use of Gramoxone (\%) & 53 & 44 & FET & $p=0.500$ \\
\hline Use of NPK fertilizer (\%) & 13 & 22 & FET & $p=0.486$ \\
\hline Use of chicken dung (\%) & 0 & 33 & FET & $p=0.042 * *$ \\
\hline $\begin{array}{l}\text { Use of compost, NPK or } \\
\text { Chicken dung (\%) }\end{array}$ & 20 & 67 & FET & $p=0.029 * *$ \\
\hline \multicolumn{5}{|l|}{ Crops grown ${ }^{\mathrm{d}}$} \\
\hline Banana cook (\%) & 73 & 44 & FET & $p=0.164$ \\
\hline Dasheen $(\%)$ & 80 & 44 & FET & $p=0.091^{*}$ \\
\hline Eggplant (\%) & 20 & 44 & FET & $p=0.208$ \\
\hline Ginger (\%) & 53 & 22 & FET & $p=0.143$ \\
\hline Napi (\%) & 80 & 33 & FET & $p=0.030^{* *}$ \\
\hline Okra $(\%)$ & 53 & 22 & FET & $p=0.143$ \\
\hline Pepper $(\%)$ & 0 & 33 & FET & $p=0.042 * *$ \\
\hline Groundnut (\%) & 33 & 56 & FET & $p=0.260$ \\
\hline Rice $(\%)$ & 73 & 33 & FET & $p=0.067^{* \mathrm{c}}$ \\
\hline Tomato $(\%)$ & 7 & 44 & FET & $p=0.047 * *$ \\
\hline Watermelon (\%) & 100 & 56 & FET & $p=0.012 * *$ \\
\hline Total number of crops grown & $9.9 \pm 0.6$ & $7.2 \pm 0.6$ & $t$-test & $t=2.814^{* *}$ \\
\hline
\end{tabular}

Farmer survey of 24 farmers in NLC

${ }^{a}$ Fisher's Exact Test (FET) or student's $t$-test, including degrees of freedom (df) in case of unequal variance

${ }^{\mathrm{b}}$ Statistical significance: $* P<0.1 ; * P<0.05$; $* * P<0.01$; ns: not significant

${ }^{\mathrm{c}}$ When applying the Tocher ratio: $P<0.05$

${ }^{\mathrm{d}}$ Excluding both crops of minor importance and crops universally grown

criterion is the amount of standing vegetation. Biomass accumulation of regenerating vegetation after burning drastically declines after five years, while it takes 10 years of fallowing to restore $75 \%$ of organic material in the soil (Dorland et al. 1988). Thus, soil restoration lags behind of biomass accumulation, and selecting a plot on the basis of the amount of vegetation does not necessarily indicate a fertile soil. Two elderly villagers mentioned that plant species were used in OL as indicator to select a plot. This traditional ecological knowledge has probably declined. 
Although our results are not conclusive, this could be due in part to the transmigration process, either because the new area confronted the villagers with different ecological characteristics or due to a disruption of intergenerational knowledge transfer (or both).

The tradition of one or two year cultivation and the historical abundance of land of the Saramaccans explain why SFM practices at plot-level were not necessary in the past. However, in the last decades farmers have adopted and adapted several external SFM practices such as reusing weeds without burning, making compost, planting groundnut, using additional fertilizers, and planting kudzu or grass to prevent soil erosion.

Reconstructing Farmers' Behavioral Intentions with the Theory of Planned Behavior

Table 5 shows how behavioral intention or observed behavior can be reconstructed from the underlying factors, which are discussed below.

\section{Changing Attitudes Towards Soil Fertility Management}

In OL farmers relied mostly on burning to suppress weeds. In the one-year cultivation period they practiced they had little opportunity to learn from the application of SFM practices on the plot as they would leave the field before these practices would sort effect. Farmers did develop knowledge on the particular places where various crops would perform best, such as planting maize along tree trunks. However, the basis for SFM was the plot selection process in which distance was not an important criterion: frequent use was made of little huts in the forest (pandaaki's) to save time walking back and forth every day (Hoeree 1983; key informants).

Although some elderly women still burn weeds, most shifting cultivators put weeds on piles for later use after they have shriveled or decomposed, or directly use them as mulch. In the first case, the externally introduced practice of re-using plant debris is combined with traditional practice (piles). Whatever the current practice, piles or mulch, farmers experienced a lower work load and noticed improved crop production. Shifting cultivators also apply NPK to remediate poor crop performance. The know-how of composting seems to be mostly embedded in the women's organizations in NLC, to which it was introduced by PAS. Its effect is appreciated in home gardens. Shifting cultivators generally do not perceive the need for composting on their plots as there are enough nutrients available during the first two years after burning. This is in line with Denevan's (1983) statement that knowledge of a certain technique does not necessarily lead to adoption, but rather the perceived need. Shifting cultivators, and even more so semi-permanent cultivators, prefer to have their plots close their homes and try to avoid long distances from the main road or river to their plot, a preference also observed elsewhere (Sirén 2007). From the above, it appears that shifting cultivators have a propensity to adopt SFM practices not with the intention to maintain soil fertility on the plot but to reduce labor input, or boost crop performance and yield. However, shifting cultivators will move to another plot if bad yields are observed and are therefore considered to have a negative attitude towards SFM at the plot level.

Semi-permanent cultivators have developed a positive attitude towards the cultivation of groundnut and other Leguminosaea, which in a slash and burn system can help replenish nitrogen volatilized during the burning phase (Budelman and Ketelaars 1974). Most of the nitrogen fixed by legumes becomes available when crop residues are left on the plots (Butterworth et al. 2003). Although this is general practice, only semi-permanent cultivators experience increases in soil productivity as shifting cultivators plant groundnut as the last crop before they leave their plot. Semi-permanent cultivators also use NPK or chicken dung on a regular basis as an intentional SFM practice. A few semi-permanent cultivators made compost on their plot. They used methods different to the one introduced by PAS. Semi-permanent cultivators are facing, or know that they will soon face, the problem of declining soil fertility and often described how they maintain or plan to maintain the soil productive with the practices discussed above. In this way they experience the benefits and constraints of SFM practices at plot-level and generate local knowledge. Semipermanent cultivators start believing they have sufficient knowledge to maintain soil fertility on their plots and have developed a positive attitude towards SFM.

\section{Farmers' Self-Identity and Subjective Norms}

In OL, shifting plots was the norm. Authorities at the village level were respected and involved in decisionmaking regarding allocation of plots. As all farmers were fully engaged in shifting cultivation, they took pride in selecting the best land-even if it required them to travel further to their plots. An exception was made for the elderly, whose plots were close by, out of respect. Such pragmatic considerations overruling known best practice were also reported by Winklerprins and Barrera-Bassols (2004) for Amerindian cases.

The adoption of plot-level SFM practices went hand in hand with the 'western view' on shifting cultivation: that it is destructive and unsustainable. In this context, semipermanent cultivators started to develop their shifting cultivation system towards 'modern' agriculture as practiced along the coast in Suriname. We found different 
Table 5 Explaining farmer behavior using the theory of planned behavior

\begin{tabular}{|c|c|c|c|}
\hline Factor of the TBP & The traditional cultivator in Old Lombe & The shifting cultivator in NLC & The semi-permanent cultivator in NLC \\
\hline \multirow[t]{9}{*}{ Attitudes } & SFM on plot: & SFM on plot: & SFM on plot: \\
\hline & $\begin{array}{l}\text { Burning suppresses weeds during } \\
\text { the cultivation period }\end{array}$ & $\begin{array}{l}\text { Weeding is beneficial for crop } \\
\text { performance }\end{array}$ & $\begin{array}{l}\text { Frequent weeding is beneficial } \\
\text { for crop performance }\end{array}$ \\
\hline & $\begin{array}{l}\text { Weeding for rice is advantageous } \\
\text { for crop development }\end{array}$ & $\begin{array}{l}\text { Apply NPK to remediate poor } \\
\text { crop performance }\end{array}$ & Grow groundnut as soil improver \\
\hline & Search niches for different crops & SFM on village level: & $\begin{array}{l}\text { Apply NPK \& chicken dung as } \\
\text { SFM practice }\end{array}$ \\
\hline & SFM on village level: & $\begin{array}{l}\text { Wish to have plot close to } \\
\mathrm{road} / \mathrm{river}\end{array}$ & Make compost on plot \\
\hline & Good plots may be far & & $\begin{array}{l}\text { Declining soil fertility is stress to } \\
\text { productivity }\end{array}$ \\
\hline & & & Drive to experiment on SFM \\
\hline & & & SFM on village level: \\
\hline & & & Wish to have plot close to road/river \\
\hline \multirow[t]{5}{*}{ Subjective norm } & Shifting plots after 1 year cropping & $\begin{array}{l}\text { Shifting cultivation is } \\
\text { backward }\end{array}$ & $\begin{array}{l}\text { Permanent agriculture is modern } \\
\text { 'real agriculture' }\end{array}$ \\
\hline & Respect authorities and elders & $\begin{array}{l}\text { Local knowledge is not } \\
\text { valuable }\end{array}$ & Shifting cultivation is destructive \\
\hline & & & Local knowledge is not valuable \\
\hline & & & Market thinking \\
\hline & & & Individualist entrepreneurship \\
\hline \multirow[t]{7}{*}{$\begin{array}{l}\text { Perceived behavioral } \\
\text { control }\end{array}$} & $\begin{array}{l}\text { Supportive community } \\
\text { decision-making }\end{array}$ & No land scarcity & No land scarcity \\
\hline & Meet food requirements & Undermined self-confidence & No financial constraints \\
\hline & $\begin{array}{l}\text { Access to knowledge on } \\
\text { plant niches and indicators } \\
\text { for plot selection }\end{array}$ & $\begin{array}{l}\text { Time- and financial } \\
\text { constraints }\end{array}$ & Time limitation \\
\hline & Respect spiritual beliefs & Lack of labor to clear plots & Lack modern inputs e.g. tractors \\
\hline & No knowledge of on-site SFM & Lack of access to knowledge & \\
\hline & & Lack of access to markets & \\
\hline & & Low level of collective action & \\
\hline \multirow[t]{2}{*}{$\begin{array}{l}\text { Actual behavioral } \\
\text { control }\end{array}$} & & $\begin{array}{l}\text { Land de facto scarce: } \\
\text { diminishing fallow periods }\end{array}$ & $\begin{array}{l}\text { Lack of collective action/knowledge } \\
\text { exchange }\end{array}$ \\
\hline & & $\begin{array}{l}\text { Regional soil fertility decline } \\
\text { in cultivation areas actually used }\end{array}$ & $\begin{array}{l}\text { Soil fertility decline on plots not } \\
\text { yet reversed }\end{array}$ \\
\hline \multirow[t]{3}{*}{$\begin{array}{l}\text { Intention } \\
\text { (observed behavior) }\end{array}$} & $\begin{array}{l}\text { Burning as part of } \\
\text { opening plot }\end{array}$ & $\begin{array}{l}\text { (Adopt plot-scale SFM practices } \\
\text { only if they save on labor input } \\
\text { or remediate poor crop } \\
\text { performance) }\end{array}$ & Continuous cultivation \\
\hline & Annual plot shifts & $\begin{array}{l}\text { Leave plot when production } \\
\text { reduces }\end{array}$ & (Minimum fallow practice) \\
\hline & $\begin{array}{l}\text { Leave plot when } \\
\text { production reduces }\end{array}$ & & $\begin{array}{l}\text { (Weed control by applying } \\
\text { gramoxone) }\end{array}$ \\
\hline
\end{tabular}

indications that semi-permanent cultivators regard themselves as farmers who practice 'modern' agriculture and judge people who practice shifting cultivation as backward, including:

- Semi-permanent cultivators' perception of agriculture as being the exclusive domain of a permanent, marketoriented activity with tools and inputs like tractors and NPK/chicken dung and as opposed to shifting cultivation;
- Semi-permanent cultivators' shorter plot distance (no consideration for elderly farmers); and

- A decline of respect towards people who still support the traditional belief system.

This self-identity and subjective norms probably lead semi-permanent cultivators to avoid fallowing for longer periods because this is associated with shifting cultivation. Shifting cultivators, on the other hand seem to undermine 
their way of crop production while they feel that too radical changes are needed for improvements. Supporting arguments for this statement are described in farmers' perceived and actual behavioral control (see next section).

A further subjective norm exists which effectively limits collective actions on a regional (village) level. This process of individualization was indicated in interviews as "Everybody on his own". The failing 'village connectivity' seems to have exacerbated the segmentation and marginalization of groups according to different identifications, including semi-permanent cultivators and shifting cultivators. These different identifications introduce a risk of undermining certain groups and creating social pressures, whereby the semi-permanent cultivators form the strongest reference group for farmers to guide their behavior on SFM.

\section{Farmers' Perceived Behavioral Control}

In OL farmers felt in control of shifting cultivation by a supportive governance structure overseeing plot allocation at the village level. There was a strong perceived need for food security, which explains why farmers would invest a lot of time in annual plot selection, and why they would stay overnight on far-away plots if necessary. The traditional cultivators had accumulated a wealth of ecological knowledge relevant for plot selection. Spiritual beliefs were strongly embedded in society and respected by all. These characteristics provided all ingredients for successful knowledge exchange-for example among generations. Other studies have also shown that local ecological knowledge is not shared equally among constituent groups, but varies according to such characteristics as age and gender (Ayantunde et al. 2008; Clark et al. 2008).

Although currently the average length of fallow periods and distance to plots have declined, the customary laws on land tenure are perceived as flexible and no appreciable conflicts with regard to land-tenure in NLC were recorded (Knoblauch 2006). Plots along the river and creeks are perceived as most fertile but farmers, while they can, do not bother to negotiate access to those lands. Many people migrate out of the village, so that abundant land becomes available for other villagers. Thus, it seems that both shifting cultivators and semi-permanent cultivators do not perceive land to be scarce. The individualist behavior of the semi-permanent cultivators as strongest reference group with their disregard towards the traditional agricultural system probably has undermined the selfconfidence of shifting cultivators. This lack of selfconfidence manifests itself as a perceived incapacity to develop solutions, by persistently viewing more constraints than opportunities in every aspect. Shifting cultivators (mostly women) have no off-farm work, often have many children to care for and experience a lack of support of men. Therefore, financial capital, labor and time limitations were perceived as constraints towards the use of fertilizers or making compost on their plot. Many shifting cultivators also perceive a lack of agricultural knowledge. The willingness to gain knowledge from cultural transmission is limited since this knowledge is valued as inadequate to practice productive agriculture and generate off-farm income. Although willingness to gain external knowledge is high, the perceived ability of farmers to gain this knowledge is limited due to infrequent visits of the village by external organizations (PAS), lack of off-farm work in the agricultural sector, suspended knowledge exchange and experimentation by the women's organizations, and a high perceived threshold (linked to low self-confidence) to go to the LVV-office in Klaaskreek to ask for advice. As the economy changed from selfreliant (identification as an economic unity on Bee level) in OL to dependence on market access (as individual participant in the national market) farmers perceive an increased need to get control over market access. Berdegué Sacristán (2001) points out that farmers benefit from cooperation through access to markets, information and extension, (agricultural) inputs, credit and transport facilities. Most shifting cultivators believed that cooperation in selling products would give them better marketing opportunities. Some women (shifting cultivators) are part of a relatively new form of cooperation set up by extension services. These women's organizations perceive a lack of control over their collective activities and thus, market access as well.

Semi-permanent cultivators on the other hand do not feel constrained by external services. They learn by individual experimentation and search for market opportunities by themselves. They perceive collective actions and knowledge exchange with other villagers as inefficient. This was also inferred from the low uniformity in SFM practices among semi-permanent cultivators. Many semi-permanent cultivators have off-farm income. Therefore they do not perceive financial constraints but are able to invest and probably perceive a lower risk of crop failures. However, their off-farm work indicates also that they have less time for agricultural activities than full-time farmers. Many parttime farmers preferred a plot near their homestead and practice less time-consuming weed management with gramoxone. Thus, semi-permanent cultivators are able to overcome financial and to some extent time constraints. Whether the use of chemical herbicides such as gramoxone solely depends on the factors mentioned here is questionable: Godoy (1998) could not confirm hypotheses of the degree of market integration (and other household and village attributes) on adoption from a statistical analysis among Bolivian lowland farmers. 
The Missing Link Between Intention and Behavior: the Role of Actual Behavioral Control

The issue of human land pressure is rarely raised by villagers in NLC. A rough estimation, assuming that 200 farmers live in NLC with land availability up to four kilometers in-land from the Suriname River, gives a density of 16 farmers $/ \mathrm{km}^{2}$. Budelman and Ketelaars (1974) estimated a maximum carrying capacity of the soils under shifting cultivation of 20 farmers $/ \mathrm{km}^{2}$. The know-how to maintain soil fertility is to some extent available among shifting cultivators which might be useful for them since shifting cultivators also have developed a preference for having plots at a closer distance, which has resulted in a more concentrated shifting cultivation area in NLC. At the same time, the fallow period of shifting cultivators' plots is now 4-10 years, while $12-20$ years is needed in order to maintain soil productivity (Budelman and Ketelaars 1974). This land use intensification process may cause changes of the biophysical environment, making fertile land de facto increasingly scarce, and the cultivated land less and less productive. Thus, although shifting cultivators intend to shift plots when production lowers, carrying out this behavior in the confined area they choose to exploit will ultimately reach an actual limit. As a consequence, walking distances to plots would then have to increase again (Sirén 2007).

Semi-permanent cultivators on the other hand may feel confident of their capacity to keep the soil on their plots fertile; they have not yet proven that their management efforts actually reverse the process of soil fertility decline. Scoones and Thompson (1994) state that farmers are more aware of the need to make the best use of their land when it is perceived to be scarce. The soil map (Fig. 2) showed that the generally appreciated blakka doti moxsi santi doti on the river terraces between Nieuw Lombé and Kapasikele were perceived as bad soils. Thus, farmers do perceive spatial differences in soil quality. However, indications that people are aware of the irreversible process that land can turn less productive are only found in the short term on the plot level (blakka doti turns into santi doti). There is an inherent weakness in the semi-permanent cultivator's strategy of individual experimentation to overcome soil fertility decline, and their lack of interest in collective action and knowledge exchange may impose an actual limit on their intention to remain on their plot indefinitely.

Of a different nature is the debate over whether shifting cultivators and semi-permanent cultivators are capable of actively pursuing their interests, and to adopt the behavior that fits their intention, under the rapidly changing conditions they are facing. Here, we turn to arguments from political ecology, in particular a recent account by Fox et al. (2009) presented for the shifting cultivation systems of South-East Asia. The perception of shifting cultivators as backward and in need of 'modernization' goes a long way back in Suriname as well. Maroon treaties with colonial authorities have long safeguarded a status-quo, as neither party was initially interested in the territory occupied by the other. This changed when the colonial, and later the national government, claimed ownership of Surinam's interior and started prospecting for mineral and forestry resources. The transmigration of 1964 was a direct consequence of the unilateral development of aluminum mining operations requiring hydro-electrical power-and the construction of the dam that submerged Maroon territory. The churches evangelizing Maroons, the colonial Dutch education system and arguably also the development organizations (e.g., PAS) that came to work in NLC, have done so with a backward image of shifting cultivation. Thus, the current negative self-identity of the shifting cultivator and the drive of semi-permanent cultivators to 'wash off' this image, stem from external pressures that until today constitute a factor of actual behavioral control. In the specific case of NLC, direct land right conflicts due to the government not recognizing shifting cultivation as a legitimate land use (another important factor mentioned by Fox et al. for South-East Asia) have not occurred. Tensions between Maroons and the government do however exist in nearby areas where gold mining and logging concessions were issued on village resource lands; the legal issues have not yet been resolved (Knoblauch 2006). The transmigration villages north of the reservoir were constructed on old logging concessions, and for constructing the dam, a highvoltage electricity transport line and the villages themselves a road network was developed triggering interest for subsequent natural resource extraction activities. However, this has not led, as in many other countries, perhaps most notably Brazil and Indonesia, to an influx of new people engaged with commercial farming or cattle ranching. The very low overall population density in Suriname (less than three inhabitants $/ \mathrm{km}^{2}$ ), and availability of more productive land in the coastal zones can explain this difference. The major factor transforming the shifting cultivation system of the Maroons in NLC is the proximity to the capital city, which exerts an apparent attraction on young people to its labor and commodity markets. This is, according to Fox et al. (2009), the least understood factor in the decline of shifting cultivation systems. Here we deem our behavioral perspective particularly appropriate, as any change (= performed behavior) is a result of an individual's behavioral intention and perceived and actual behavioral control. Somehow, semi-permanent cultivators both wish to and succeed in participating in the market economy while shifting cultivators do so to lesser extent. It is our conviction that it is this intention that drives semipermanent cultivators, and in turn gives them the opportu- 
nities (or need!) to practice plot-level SFM practices (c.f. Kaiser et al. 1999; Wauters et al. 2010). For shifting cultivators, it is hard to say whether SFM practices applied depend primarily on their intention, subjective norms, or perceived or actual behavioral control; they seem to 'go with the flow'. Extension of the TPB to include the relation between market opportunities and behavioral intentions of Maroons is necessary to establish which factors prevail. Such a study should include the category of (ex-)villagers who quitted farming altogether to pursue off-farm work in order to provide conclusive results.

\section{Conclusions}

Ajzen's TPB states that behavior is a direct consequence of farmers' intention. This study confirmed the relation between farmers' intention and behavior on SFM.

The cultivation period can be considered the most significant determinant of farmers' capabilities to maintain their land in fertile condition since farmers will face the problem of soil fertility decline only after a certain cultivation period. One group of farmers (mostly women) moves to another area when bad yields are observed, while another group (mostly men) attempts to stay longer than two years on the same plot and has to adapt management practices to the biophysical changes of the environment. This study shows significant differences between these groups, which we named shifting cultivators and semipermanent cultivators respectively. These differences can be explained from farmers' attitude, subjective norms and perceived behavioral control.

Formerly, farmers' behavior towards the elements of the natural environment by their traditional belief system. Nowadays, farmers undervalue their traditional way of shifting cultivation compared to 'modern' agriculture and have a strong drive to generate financial capital as a result of the perceived attractiveness of the 'modern society'. Planting groundnut and, less often, using additional fertilizers or composting is adopted in the current generation from external sources. Shifting cultivators apply these SFM practices not with the purpose to maintain soil fertility but because of perceived crop performance, labor-intensity, access to markets, and/or time and financial constraints. In addition to these factors the extent to which shifting cultivators want to control soil fertility on their plot is generally low-they are strong on their tradition of shifting cultivation. In contrast, semi-permanent cultivators perceived to some extent control over time, financial capital, access to knowledge and markets. Moreover most of them seem to be aware of the potential risk of declining soil fertility and generate site-specific knowledge by experimentation with SFM.
Farmers are found to be not aware of the long-term effect of land degradation. Access to land is found not to be a problem and as long as high emigration rates prevail, the risk of land degradation due to the agricultural activities of shifting cultivators is expected to be low. Semi-permanent cultivators were identified as the strongest reference group for farmers to guide their SFM behavior. However, the motivation for shifting cultivators to emulate this reference group is low because of farmers' perceived lack of capabilities to change their traditional agricultural system. Nevertheless the growing awareness that putting weeds on piles is more effective than burning shows that changes are possible but occur slowly. The risk of land degradation is arguably highest among semi-permanent cultivators on less fertile soils, but this study also showed that they are more adaptive than shifting farmers. However, biophysical data collected over an extended period are needed to evaluate the actual threat of land degradation, and to determine whether the Maroons in NLC are adaptive enough to withstand the changed conditions, after the transmigration, in order to maintain their soil fertility and prevent land degradation.

An understanding of behavioral changes is essential in order to enhance farmers' sustainability of land management instead of developing intervention programs without knowing 'local realities'. Any (external) effort to increase sustainability of the Maroon farming systems should understand the different attitudes and perceived behavioral controls of shifting cultivators and semi-permanent cultivators and target them according to their intentions and limitations. Shifting cultivators are limited by their perceived behavioral controls in terms of time, finances, access to knowledge, and access to markets which results in a lack of self-confidence. They can be assisted in strengthening their capabilities for collective action on access to markets and plot rotation systems. Adequate SFM should be implemented on a regional level since shifting cultivators frequently switch fields. Farmers who intend to practice permanent agriculture are probably mostly limited by a lack of ecological knowledge and can individually be consulted on their experimentations as they have suggested themselves. Shifting cultivators will likely adapt the successes of these experiments when knowledge exchange within the village can be assured. Therefore, institutional capacity building at village level should be considered in order to support the divergent development pathways that will likely result from such a focused intervention strategy. Interestingly, by acknowledging the pioneering efforts of semi-permanent cultivators and stressing the need for sharing lessons learned from experimentation on the one hand, and strengthening the self-identity of shifting cultivators and securing markets for their products on the other, ecological, economical and social sustainability at the village level may automatically grow. 
Acknowledgements This study was conducted under the Guyagrofor project. Guyagrofor is the acronym for: Development of sustainable agroforestry systems based on indigenous and maroon knowledge in the Guyana shield region. This project has received funding of the European Community's Sixth Framework Program. Comments by Dr. Mark Reed and three anonymous reviewers greatly benefited the paper.

Open Access This article is distributed under the terms of the Creative Commons Attribution Noncommercial License which permits any noncommercial use, distribution, and reproduction in any medium, provided the original author(s) and source are credited.

\section{References}

ABS (2005). Bevolkingsstatistieken 2004-2005. Stichting Algemeen Bureau voor de Statistiek, Paramaribo, Suriname.

Ajzen, I. (2005). Attitudes, Personality, and Behavior, 2nd ed. Open University Press, UK.

Anderson, A. B. (1980). Recent Acculturation of Bush Negroes in Suriname and French Guiana. Anthropologica 22(1): 61-84.

Artikov, I., Hoffman, S., Lynne, D., Pytlik-Zillig, L. M., Hu, Q., Tomkins, A. L., Hubbard, K. G., Hayes, M. J., and Waltman, W. (2006). Understanding the Influence of Climate Forecasts on Farmer Decisions as Planned Behavior. Journal of Applied Meteorology 45: 1202-1214.

Ayantunde, A. A., Briejer, M., Hiernaux, P., Udo, H. M. J., and Tabo, R. (2008). Botanical Knowledge and Its Differentiation by Age, Gender, and Ethnicity. Human Ecology 36: 881-889.

Barker, D., and Spence, B. (1988). Afro-Caribbean Agriculture: a Jamaican Maroon Community in Transition. The Geographical Journal 154(2): 198-208.

Barrera-Bassols, N., and Zinck, J. A. (2003). Ethnopedology: a Worldwide View on Soil Knowledge of Local People. Geoderma 111: 171-195.

Beedell, J., and Rehman, T. (2000). Using Social-Psychology Models to Understand Farmers' Conservation Behavior. Journal of Rural Studies 16: 117-127.

Berdegué Sacristán, J.A. (2001). Cooperating to Compete: Associative Peasant Business Firms in Chile. PhD Thesis, Wageningen University, The Netherlands.

Berkes, F., Colding, J., and Folke, C. (2000). Rediscovery of Traditional Ecological Knowledge as Adaptive Management. Ecological Applications 10(5): 1251-1262.

Beshah, T. (2003). Understanding Farmers, Explaining Soil and Water Conservation in Konso, Wolaita and Wello, Ethiopia. Tropical resource Management Papers no. 41. Wageningen University, The Netherlands.

Biot, Y., Blaikie, P. M., Jackson, C., and Palmer-Jones, R. (1995). Rethinking Research on Land Degradation in Developing Countries. World Bank Discussion Papers No 289. World Bank, Washington, D.C.

Birmingham, D. (1998). Learning Local Knowledge of Soils: a Focus on Methodology. Indigenous Knowledge and Development Monitor 6(2): 7-10.

Budelman, A., and Ketelaars, J. J. M. H. (1974). Een studie van het traditionele landbouwsysteem onder de boslandcreolen. Centrum voor Landbouwkundig Onderzoek in Suriname (CELOS) rapport nr. 96, Paramaribo, Suriname.

Burton, R. J. F. (2004). Reconceptualising the 'Behavioral Approach' in Agricultural Studies: a Socio-Psychological Perspective. Journal of Rural Studies 20: 359-371.

Butterworth, J., Adolph, B., and Suresh Reddy, B. (2003). How Farmers Manage Soil Fertility. A Guide to Support Innovation and Livelihoods. Andhra Pradesh Rural Livelihoods Project, Hyderabad / Natural Resources Institute, Chatham.

Clark, L. G., Bilsborrow, R. E., Bremner, J. L., and Lu, F. (2008). Indigenous Land Use in the Ecuadorian Amazon. A CrossCultural and Multilevel Analysis. Human Ecology 36: 97-109.

Corbeels, M., Shiferaw, A., and Haile, M. (2000). Farmers' Knowledge of Soil Fertility and Local Management Strategies in Tigray, Ethiopia. Managing Africa's Soils No. 10. IIED, UK.

Defoer, T., and Budelman, A. (2000). Managing Soil Fertility in the Tropics. A Resource Guide for Participatory Learning and Action Research. KIT, Amsterdam, The Netherlands.

De Graaff, J., Valk, W., and Fleskens, L. (2001). Impact Assessment of Land and Water Management. Lecture Notes. Wageningen University, The Netherlands.

Denevan, W. M. (1983). Adaptation, Variation, and Cultural Geography. The Professional Geographer 35: 399-407.

Dorland, S., Kijne, A., van Paassen, M., and Schneemann, J. (1988). Shifting Cultivation nu, Multistorey Farming Straks? Project Group Shifting Cultivation. Wageningen University, The Netherlands.

Driessen, P. M., and Dudal, R. (1991). The Major Soils of the World. Wageningen Agricultural University, The Netherlands.

Eduards, M. (1996). Geldeconomie en productie voor eigen consumptie. Een onderzoek naar de economische bedrijvigheid van huishoudens in twee Saramacaanse dorpen in het district Sipaliwini. Anton de Kom Universiteit, Paramaribo, Suriname.

Fishbein, M., and Ajzen, I. (1975). Belief, Attitude, Intention and Behavior: an Introduction to Theory and Research. AddisonWesley, Reading, MA.

Fox, J., Fujita, Y., Ngidang, D., Peluso, N., Potter, L., Sakuntaladewi, N., Sturgeon, J., and Thomas, D. (2009). Policies, PoliticalEconomy, and Swidden in Southeast Asia. Human Ecology 37: 305-322.

German, L. A. (2003). Historical Contingencies in the Coevolution of Environment and Livelihood: Contributions to the Debate on Amazonian Black Earth. Geoderma 111: 307-331.

Godoy, R. (1998). Adoption of Modern Agricultural Technologies by Lowland Indigenous Groups in Bolivia: the Role of Households, Villages, Ethnicity, and Markets. Human Ecology 26: 351-369.

Green, E. C. (1978). Winti and Christianity: a Study in Religious Change. Ethnohistory 25(3): 251-276.

Heckenberger, M. J., Russell, J. C., Toney, J. R., and Schmidt, M. J. (2007). The Legacy of Cultural Landscapes in the Brazilian Amazon: Implications for Biodiversity. Philosophical Transactions of the Royal Society B 362: 197-208.

Heemskerk, M. (2003). Scenarios in Anthropology: Reflections on Possible Futures of the Suriname Maroons. Futures 35(9): 931949.

Hendrison, J. (2002). Discussion paper for the development of a framework policy and strategic plan for the sustainable management of the non-urban environmental sub-sector in Suriname. Forest and fresh water resources (Section I). WWF Guianas / Ministry of Planning and Development Cooperation (PLOS), Paramaribo, Suriname.

Hoeree, J. (1983). De Saramakaanse wereld: formatie, stabilisatie, akkulturatie. Thesis, Ghent University, Belgium.

Kaiser, F. G., Wolfing, S., and Fuhrer, U. (1999). Environmental Attitude and Ecological Behavior. Journal of Environmental Psychology 19: 1-19.

Kickert, W. J. M., Klijn, E., and Koppenjan, J. F. M. (eds.) (1997). Managing Complex Networks: Strategies for the Public Sector. Sage, London, UK.

Knoblauch, B. (2006). Land Right Conflicts in Surinam and Customary Land Rights in a Maroon Transmigration Village. Msc Thesis. Wageningen University, The Netherlands. 
Kolawole, O. D. (2001). Local Knowledge Utilisation and Sustainable Rural Development in the 21st Century. Indigenous Knowledge and Development Monitor 9(3). http://www.iss.nl/ikdm/IKDM/ IKDM/9-3/kolawole.html.

Kottek, M., Grieser, J., Beck, C., Rudolf, B., and Rubel, F. (2006). Worldmap of the Köppen-Geiger Climate Classification Updated. Meteorologische Zeitschrift 15: 259-263.

Laird, S. A. (1999). Forests, culture and conservation. In Posey, D. A. (ed.), Cultural and Spiritual Values of Biodiversity: a Complementary Contribution to the Global Biodiversity Assessment. UNEP, Nairobi, Kenya, pp. 347-358.

Lenoir, J. D. (1975). Suriname National Development and Maroon Cultural Autonomy. Social and Economic Studies 24(3): 308319.

Lynne, G. D., and Rola, L. R. (1988). Improving Attitude-Behaviour Prediction Models with Economic Variables: Farmer Actions Toward Soil Conservation. Journal of Social Psychology 128: 19-28.

Lynne, G. D., Casey, C. F., Hodges, A., and Rahmani, M. (1995). Conservation Technology Adoption Decisions and the Theory of Planned Behavior. Journal of Economic Psychology 16: 581-598.

Mackensen, J., Hölscher, D., Klinge, R., and Fölster, H. (1996). Nutrient Transfer to the Atmosphere by Burning of Debris in Eastern Amazonia. Forest Ecology and Management 86: 121128.

Maundu, P. (1995). Methodology for Collecting and Sharing Indigenous Knowledge: a Case Study. Indigenous Knowledge and Development Monitor 3(2). http://www.iss.nl/ikdm/IKDM/ IKDM/3-2/articles/maundu.html.

Mulders, M. A., and Bruin, L. P. H. (1973). Climatological aspects of the Afobaka area. Rapport nr. 117. Dienst Bodem Kartering, Paramaribo, Suriname.

Niemeijer, D. (1995). Indigenous Soil Classifications: Complications and Considerations. Indigenous Knowledge and Development Monitor 3(1). http://www.iss.nl/ikdm/IKDM/IKDM/3-1/articles/ niemeijer.html.

Oudwater, N., and Martin, A. (2003). Methods and Issues in Exploring Local Knowledge of Soils. Geoderma 111(3-4): 387-401.

Poels, R. L. H. (1989). Nutrient Input and Output in Undisturbed and Silviculturally Treated Tropical Rain Forest in Suriname. Netherlands Journal of Agricultural Science 37: 383-386.

Polletta, F., and Jasper, J.M. (2001). Collective Identity and Social Movements. Annual Review of Sociology 27: 283-305.

Pretty, J. (2003). Social Capital and the Collective Management of Resources. Science 302: 1912-1915.

Price, R. (1975). Saramaka Social Structure: Analysis of a Maroon Society in Surinam. Institute of Caribbean Studies, University of Puerto Rico, Puerto Rico.

Ruthenberg, H. (1980). Farming Systems in the Tropics, 3rd ed. Clarendon, Oxford, UK. 424p.

Saïdou, A., Kuyper, T. W., Kossou, D. K., Tossou, R., and Richards, P. (2004). Sustainable Soil Fertility Management in Benin: Learning from Farmers. NJAS Wageningen Journal of Life Sciences 52: 349-369.

Saito, K., Linquist, B., Keobualapha, B., Shiraiwa, T., and Horie, T. (2006). Farmers Knowledge of Soils in Relation to Cropping Practices: a Case Study of Farmers in Upland Rice Based Slash-and-Burn Systems of Northern Laos. Geoderma 136: 64-74.
Schmink, M., Redford, K. H., and Padoch, C. (1992). Traditional peoples and the biosphere: framing the issues and defining the terms. In Redford, K. H., and Padoch, C. (eds.), Conservation of Neotropical Forests: Working from Traditional Resource Use. Columbia University Press, New York, pp. 3-13.

Scoones, I., and Thompson, J. (1994). Knowledge, power and agriculture: towards a theoretical understating. In Scoones, I., and Thompson, J. (eds.), Beyond Farmer First: Rural People's Knowledge, Agricultural Research and Extension Practices. Intermediate Technology Publications, International Institute for Environment and Development, London, UK.

Sirén, A. H. (2007). Population Growth and Land Use Intensification in a Subsistence-Based Indigenous Community in the Amazon. Human Ecology 35: 669-680.

St-Hilaire, A. (2000). Global Incorporation and Cultural Survival: the Surinamese Maroons at the Margins of the World-System. Journal of World-systems research VI: 101-131.

Stoorvogel, J. J., and Smaling, E. M. A. (1998). Research on Soil Fertility Decline in Tropical Environments: Integration of Spatial Scales. Nutrient cycling in agroecosystems 50: 151-158.

Szott, L. T., Palm, C. A., and Buresh, R. J. (1999). Ecosystem Fertility and Fallow Function in the Humid and Subhumid Tropics. Agroforestry Systems 47: 163-196.

Tanner, C. (1999). Constraints on Environmental Behavior. Journal of Environmental Psychology 19: 145-157.

Tiffen, M., and Mortimore, M. (1994). Malthus Controverted-the Role of Capital and Technology in Growth and Environment Recovery in Kenya. World Development 22: 997-1010.

Topoliantz, S., Ponge, J.-F., and Lavelle, P. (2006). Humus Components and Biogenic Structures Under Tropical Slash-and-Burn Agriculture. European Journal of Soil Science 57: 269-278.

U.N. (2002). Dialogue Paper by Indigenous People. E/CN.17/2002/ PC.2/6/Add.3. United Nations, Economic and Social Council, New York.

Van der Pol, F. (1992). Soil Mining: an Unseen Contributor to Farm Income in Southern Mali. Royal Tropical Institute, Amsterdam, The Netherlands.

Van Vuure, W. (1971). Toelichting en advies bij zee globale bodemkaart Victoria-Brokopondo-Afobaka. Rapport nr. 119. Dienst Bodem Kartering. Paramaribo, Suriname.

Vigelandzoon, J. (2003). Development of Sustainable Agroforestry Systems based on Indigenous and Maroon Knowledge in the Guyana Shield Region. Specific Targeted Research Project. Wageningen University, The Netherlands.

Warren, D. M., Slikkenveer, L. J., and Brokensha, D. (1995). The Cultural Dimension of Development. Indigenous Knowledge Systems. Intermediate Technology, London, UK.

Wauters, E., Bielders, C., Poesen, J., Govers, G., and Matthijs, E. (2010). Adoption of Soil Conservation Practices in Belgium: an Examination of the Theory of Planned Behavior in the Agrienvironment Domain. Land Use Policy 27: 86-94.

Wiersum, K. F. (2000). Incorporating indigenous knowledge in formal forest management: adaptation or paradigm change in tropical forestry? In Lawrence, A. (ed.), Forestry, Forest Users and Research: New Ways of Learning. European Tropical Forest Research Network, Wageningen, The Netherlands, pp. 19-32. ETFRN Series No. 1.

Winklerprins, A. M. G. A., and Barrera-Bassols, N. (2004). Latin American Ethnopedology: Its Past, Present, and Future. Agriculture and Human Values 21: 139-156. 